\title{
Cytotoxic agent against human gastric carcinoma cells from a kind of Danaidae and its host plant
}

\author{
By Kotaro Koyama ${ }^{*}$ ) Masaki BabA, ${ }^{*)}$ Masahiko Watanabe ${ }^{*)}$ Hiroaki TaKahashI, ${ }^{* *}$ \\ Haruo IshiYama, ${ }^{* *)}$ Takashi SugimuRA, ${ }^{*)}$ M.J.A., and Keiji WAKABAYASHI ${ }^{*)}$ \\ (Contributed by Takashi SugimuRA, M. J. A., Jan. 12, 1999)
}

\begin{abstract}
Cytotoxic activity of chloroform-methanol extracts from 92 kinds of butterflies was tested in vitro against human gastric carcinoma TMK-1 cells. Among the species tested, cytotoxicity was found only in a kind of Danaidae, Ideopsis similis, with an $\mathrm{IC}_{50}$ value at the $5 \times 1 / 10^{6}$ dilution. The other butterflies showed no activity, even at a dilution of $1 / 10^{2}$. Cytotoxic activity was also detected in chloroform-methanol extract from leaves of Tylophora tanakae, a food source for caterpillars of I. similis. The active principles in I. similis were thus suggested to be derived from compounds present in the leaves of T. tanakae.
\end{abstract}

Key words: Cytotoxic agent; gastric carcinoma cell; Danaidae; Ideopsis similis; Tylophora tanakae.

As part of the search for cancer cures, an extensive screening for anti-cancer drugs started about 40 years ago. Tremendous numbers of compounds have been examined in in vitro and in vivo test systems, but, the number of chemotherapeutic agents which have become approved for clinical application is less than $100 .{ }^{1,2)}$ Taking a variety of types of cancer and the effectiveness of available agents into consideration, further studies of new anti-cancer compounds are required.

Compounds tested are chemically synthesized substances, natural compounds and biotechnology products. Test compounds from natural sources are mainly of fungal or plant-origin. Among naturally occurring compounds having anti-cancer activities, several compounds have been clinically used as anti-cancer drugs; for example, paclitaxel from Taxus brevifolia, camptothecin from Camptotheca acuminata and adriamycin from Streptomyces peucetius. ${ }^{3)-6)}$ However, reports describing anti-cancer activity substances derived from insect sources are very limited. ${ }^{7), 8)}$ Recently, we examined cytotoxic activity in extracts of pupae and adults of 20 kinds of butterflies and moths against a human gastric carcinoma cell line, TMK-1, in

\footnotetext{
*) Cancer Prevention Division, National Cancer Center Research Institute, 5-1-1 Tsukiji, Chuo-ku, Tokyo 104-0045, Japan.

**) Terumo Research and Development Center, 1500 Inokuchi, Nakai-machi, Asigarakami-gun, Kanagawa 259-0151, Japan.
}

vitro, and found activity in three species of butterflies, Pieris rapae, Pieris napi and Pieris brassicae. ${ }^{9)}$ The active principle, named pierisin, in the pupae of $P$. rapae was elucidated to be protein having a molecular weight of $98 \mathrm{kDa}^{10)}$ Pierisin showed cytotoxic effects against various kinds of human cancer cell lines including TMK-1, with $\mathrm{IC}_{50}$ values ranging from $0.043 \mathrm{ng}$ to 150 $\mathrm{ng} / \mathrm{ml}^{10), 11)}$

During the search for new bioactive materials such as anti-cancer agents in insects, we incidentally noticed the possible presence of anti-cancer agent having a low molecular weight and a non-proteinous nature in butterfly. Therefore, in the present study we prepared extracts from adults of various butterflies with chloroform-methanol solution and tested their cytotoxicity in vitro against the TMK-1 cell line. Dried samples of 92 kinds of adult butterfly, listed in Table I, were obtained from the Mokusei butterfly museum, Taiwan. Whole bodies of the adult butterflies were weighed, finely dissected and extracted with 50 volumes of chloroform-methanol $(1: 1, \mathrm{v} / \mathrm{v})$ solution for $1 \mathrm{hr}$ at room temperature with shaking. The extract solutions were filtered, and residual material was again extracted with chloroform-methanol solution under the same conditions. The resultant solutions were combined and evaporated to dryness under reduced pressure.

The extract samples were suspended in 10 volumes of water equivalent to original sample weight and tested for cytotoxicity. For this purpose, near-confluent TMK-1 
cells were trypsinized, collected and diluted to $10^{5}$ cells $/ \mathrm{ml}$ with RDF medium containing $10 \%$ fetal calf serum (Gibco BRL, Gaithersburg, MD). Aliquots of $100 \mu \mathrm{l}$ of the cell suspension containing $10^{4}$ cells were dispensed into each well of 96 -well plates and combined with diluted samples of the extracts. After $48 \mathrm{~h}$ incubation at $37^{\circ} \mathrm{C}$ in $5 \% \mathrm{CO}_{2}$ in air, cytotoxic effects were measured with an XTT cell proliferation assay kit (Boehringer Mannheim, Mannheim, Germany).

Chloroform-methanol extract samples were diluted

Table I. Species of butterfly examined in the present study

\begin{tabular}{cl}
\hline Family & \multicolumn{1}{c}{ Species } \\
\hline Papilionidae & Byasa polyeuctes, Chilasa agestor, Chilasa \\
& epycides, Graphium cloanthus, Graphium \\
& doson, Graphium sarpedon, Pachliopta aris- \\
& tolochiae, Papilio bianor, Papilio dialis, \\
& Papilio helenus, Papilio hoppo, Papilio \\
& machaon, Papilio nephelus, Papilio paris, \\
& Papilio protenor, Papilio thaiwanus, Papilio \\
& xuthus, Princeps demoleus
\end{tabular}

Pieridae Appias lyncida, Catopsilia pomona, Catopsilia pyranthe, Cepora nadina, Cepora nerissa, Colias erate, Delias hyparete, Delias lativitta, Eurema andersoni, Eurema blanda, Eurema brigitta, Eurema hecabe, Eurema laeta, Gonepteryx amintha, Hebomoia glaucippe, Ixias pyrene, Pieris canidia, Pieris rapae, Prioneris thestylis

Lycaenidae Acytolepis puspa, Celastrina argiolus, Celastrina oreas, Chrysozephyrus esakii, Curetis acuta, Curetis brunnea, Heliophorus ila, Lampides boeticus, Prosotas nora, Syntarucus plinius, Udara dilecta

Libytheidae Libythea celtis

Danaidae Anosia chrysippus, Euploea mulciber Euploea sylvester, Idea leuconoe, Ideopsis sim ilis, Parantica aglea, Parantica melaneus, Parantica sita, Salatura genutia, Tirumala septentrionis

Nymphalidae Athyma asura, Athyma cama, Calinaga buddha, Cyrestis thyodamas, Dichorragia nesimachus, Hestina assimilis, Kaniska canace, Limenitis sulpitia, Neptis nata, Neptis philyra, Neptis sappho, Neptis taiwana, Pantoporia hordonia, Polygonia c-album, Polygonia c-aureum, Polyura eudamippus, Polyura narcaea, Precis almana, Precis iphita, Precis lemonias, Precis orithya, Sephisa daimio, Sumalia dudu, Symbrenthia javanus, Timelaea albescens, Vanessa indica

Satyridae Elymnias hypermnestra, Lethe insana, Penthema formasanum

Hesperiidae Ampittia virgata, Pelopidas mathias, Satarupa gopala, Seseria formosana

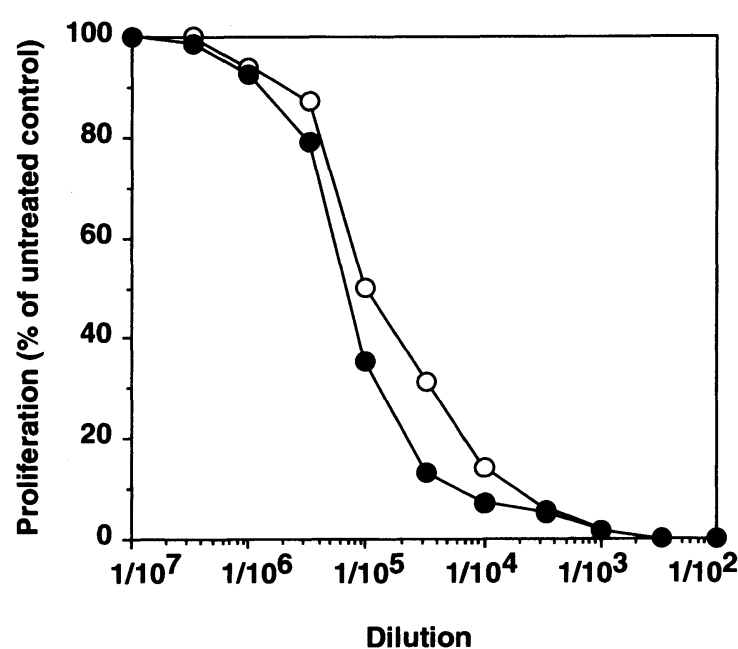

Fig. 1. Dose-response curves of cytotoxic activity against TMK-1 cells of extracts from I. similis and T. tanakae. Extract samples at various dilutions were incubated with human gastric carcinoma TMK-1 cells for $48 \mathrm{hr}$ and subjected to XTT cell proliferation assay. The values at each point are the means of three independent assays. I. similis: (O), T. tanakae: (O).

step-wise at one-tenth concentrations. Among 92 kinds of butterfly samples including Papilionidae, Pieridae, Lycaenidae, Libytheidae, Danaidae, Nymphalidae, Satyridae and Hesperiidae, only the extract sample from a kind of Danaidae, Ideopsis similis showed strong cytotoxic activity, down to a dilution of $1 / 10^{5}$, reducing the numbers of surviving cells to less than $50 \%$. Other butterfly samples did not exhibit any cytotoxicity, even at the $1 / 10^{2}$ dilution. The dose-response of the cytotoxicity of the extract from $I$. similis was examined at dilutions of $1 / 10^{7}-1 / 10^{2}$. As shown in Fig. 1, dose-dependent cytotoxicity was observed, with an $\mathrm{IC}_{50}$ value at the dilution of $5 \times 1 / 10^{6}$.

I. similis feeds on leaves of Tylophora tanakae during its larval age. To cast light on the origin of the cytotoxic substance in I. similis, cytotoxic activity against TMK-1 cells of leaves from $T$. tanakae was examined. Leaves of T. tanakae were collected from Iriomote island in Okinawa prefecture, dried and extracted with chloroform-methanol solution under the same conditions used for the butterfly samples. The extract showed cytotoxic activity in a dose-dependent manner, with the $\mathrm{IC}_{50}$ value at the $1 / 10^{5}$ dilution (Fig. 1). Chloroform-methanol extract from adults of $I$. similis collected in the same area at Iriomote island also demonstrated cytotoxicity against TMK-1 cells, the activity being very similar to that for I. similis obtained in Taiwan. Furthermore, the cytotoxicity was also observed in the larvae and pupae of I. similis obtained 
from Iriomote island

The cytotoxic active substance(s) extractable with chloroform-methanol solution from both $I$. similis and $T$. tanakae were found to be heat-stable $\left(80^{\circ} \mathrm{C}, 30 \mathrm{~min}\right)$, suggesting a non-proteinous nature. Preliminarily, most of the cytotoxic activity was found to be recovered in the basic fraction of chloroform-methanol extracts from both $I$. similis and T. tanakae. It has been reported that several phenanthroindolizidine alkaloids exist in the leaves of T. tanakae, and some of them showed oviposition stimulant activities for $I$. similis. ${ }^{12)-14)}$ Since $T$. tanakae is known as a food source for caterpillars of $I$. similis, it is most likely that phenanthroindolizidine alkaloids and their metabolites are present to some extent in the bodies of $I$. similis, and some of these could exhibit cytotoxicity against TMK-1 cells. In order to elucidate this possibility, isolation and identification of the active principles in I. similis and T. tanakae exerting cytotoxicity against TMK-1 cells are now under investigation in our laboratory.

Acknowledgments. We greatly thank Dr. Nakahide Nakayama (Director of Hiroshima Forest Park Insectarium) for his cooperation in collecting $I$. similis and T. tanakae from Iriomote island. This study was supported by a Grant-in-Aid for Cancer Research from the Ministry of Health and Welfare, Japan, as well as by a grant from the Japan Cultural Institute.

\section{References}

1) Weinstein, J. N., Myers, T. G., O'Connor, P. M., Friend, S. H., Fornace, A. J. Jr., Kohn, K. W., Fojo, T., Bates, S. E., Rubinstein, L. V., Anderson, N. L., Buolamwini, J. K., van Osdol, W. W., Monks, A. P., Scudiero, D. A., Sausville, E. A., Zaharevitz, D. W., Bunow, B., Viswanadhan, V. N., Johnson, G. S., Wittes, R. E., and Paull, K. D. (1997) Science 275, 343-349.

2) Gura, T. (1997) Science 278, 1041-1042.

3) Pezzuto, J. M. (1996) Biochem. Pharmacol. 53, 121-133.

4) Wall, M. E., and Wani, M. C. (1995) Cancer Res. 55, 753-760.

5) Wall, M. E. (1998) Med. Res. Rev. 18, 299-314.

6) Arcamone, F., and Cassinelli, G. (1998) Curr. Med. Chem. 5, 391-419.

7) Moore, A. J., Devine, D. A., and Bibby, M. C. (1994) Pept. Res. 7, 265-269.

8) Nakajima, H., Komano, H., Esumi-Kurisu, M., Abe, S., Yamazaki, M., Natori, S., and Mizuno, D. (1982) Gann 73 627-632.

9) Koyama, K., Wakabayashi, K., Masutani, M., Koiwai, K., Watanabe, M., Yamazaki, S., Kono, T., Miki, K., and Sugimura, T. (1996) Jpn. J. Cancer Res. 87, 1259-1262.

10) Watanabe, M., Kono, T., Koyama, K., Sugimura, T., and Wakabayashi, K. (1998) Jpn. J. Cancer Res. 89, 556-561.

11) Kono, T., Watanabe, M., Koyama, K., Kishimoto, T., Fukushima, S., Sugimura, T., and Wakabayashi, K. (1999) Cancer Lett. (in press).

12) Abe, F., Iwase, Y., Yamauchi, T., Honda, K., and Hayashi, N. (1995) Phytochemistry 39, 695-699.

13) Honda, K., Tada, A., Hayashi, N., Abe, F., and Yamauchi, T. (1995) Experientia 51, 753-756.

14) Abe, J., Hirokawa, M., Yamauchi, T., Honda, K., Hayashi, N., Ishii, M., Imagawa, S., and Iwahara, M. (1998) Chem. Pharm. Bull. 46, 767-769. 